\title{
Current perspectives on the spread of plague in Africa
}

This article was published in the following Dove Press journal:

Research and Reports in Tropical Medicine

22 May 2015

Number of times this article has been viewed

\section{Wael Mohamed Lotfy}

Parasitology Department, Medical Research Institute, Alexandria University, Alexandria, Egypt
Correspondence: Wael Mohamed Lotfy Parasitology Department, Medical Research Institute, I65 El-Horreya Avenue, Alexandria, Egypt Tel +20100815 4959

Email waelotfy@alexu.edu.eg
Abstract: Plague is a zoonotic disease which has been responsible for a number of high-mortality epidemics throughout the recorded human history. This review was carried out with the aim of evaluating the current situation of human plague in Africa. The disease was reported from at least 28 countries in the continent, among them eight countries are currently with active human foci. The Democratic Republic of the Congo and Madagascar are the countries with the highest endemicity in the world. A unique gathering of factors involved in the disease re-emergence in other parts of the world is present in Madagascar. The risk factors affecting persistence and spread of plague in the country were briefly reviewed. Based on the data presented, it was concluded that all African countries should be concerned by the possible emergence/re-emergence of the disease. It is crucial to implement some preventive measures in these countries. These measures include surveillance of suspected natural foci, rodent and insect eradication campaigns, and public health education.

Keywords: emergence, re-emergence, disease, plague, Africa, public health

\section{Introduction}

Plague is a rapidly progressing zoonotic disease. It has been responsible for a number of high-mortality epidemics throughout the recorded human history. It is one of three epidemic diseases still subject to the International Health Regulations and notifiable to the World Health Organization (WHO). Plague natural foci are still found in the tropical and sub-tropical latitudes, and in the warmer parts of the temperate latitudes around the globe, between the parallels $55^{\circ}$ North and $40^{\circ}$ South. ${ }^{1}$ Known disease foci are found on all continents except Australia; most probably the disease did not succeed to colonize the continent due to its failure to become established in a suitable enzootic host. ${ }^{2}$ Since the beginning of the 1990s, the number of human cases has been rising, and outbreaks are reappearing in various countries of the world after decades of quiescence. Presently, human plague infections continue to occur in Africa, the former Soviet Union, the Americas, and Asia. ${ }^{3}$ Due to the high public health significance of plague and the risk of its re-emergence, the present review was carried out with the aim of evaluating the current situation of the disease in Africa. Among our goals was reviewing the different factors that may be responsible for re-emergence of the disease in Madagascar as a model example. Also our goals included reviewing the suitable disease surveillance, prevention, and control measures.

\section{Routes of human plague transmission}

The causative agent of plague, Yersinia pestis, has the ability to cause disease in rodents, humans, and some other mammals. Y. pestis species includes different variants 
that have been identified based on genetic and phenotypic bases. Strains of $Y$. pestis subspecies pestis belonging to biovars Antiqua, Medievalis, Orientalis, and Intermedium are virulent for humans. ${ }^{46}$ Biovar Antiqua, resident in Africa, is descended from bacteria that caused the first pandemic. Biovar Medievalis, resident in central Asia, is descended from the bacteria that caused the second pandemic. Biovar Orientalis is currently widespread and linked to the third pandemic. ${ }^{4}$

Plague is transmitted between mammals via fleas, cannibalism or contaminated soil. ${ }^{7}$ Human plague most commonly occurs when an infected flea bites a man. ${ }^{1}$ The primary carriers of the pathogen are the Oriental rat flea, Xenopsylla cheopis, and infected rodents. ${ }^{7}$ The human flea, Pulex irritans, may play a role in human-to-human transmission of the disease during outbreaks. ${ }^{8}$ Fleas from other mammals have a role in sylvatic plague transmission and human plague outbreaks. ${ }^{9}$ In addition, the human body louse (Pediculus humanus corporis) and head louse (Pediculus humanus capitis) are incriminated in transmission of the disease. ${ }^{10-12}$ Before human epidemics, rats frequently died in large numbers, precipitating the movement of the flea population from its natural rodent reservoir to humans. In rare occasions, rodents can transmit the infection to humans through direct contact. Although most cases infected by the vector-borne route develop bubonic plague which affects the lymph nodes, a small minority will develop a form of plague termed primary septicemic plague which affects the bloodstream. ${ }^{1}$ A small percentage of patients with bubonic or septicemic plague may develop secondary pneumonic plague which affects the lungs. This form of the disease plays an important role in spread of the disease by respiratory droplets, through coughing or sneezing near another person. Persons who will be infected by this route develop primary pneumonic plague. ${ }^{1,13}$ The disease may spread, also, through direct physical contact by touching an infected person. Indirect contact is usually by touching contaminated soil. ${ }^{1}$ Oral transmission usually results from contaminated food. Domestic cats have been known to develop plague from oral mucous membrane exposure to infected rodent tissues in enzootic areas. Handling and consumption of raw or insufficiently cooked meat of infected animals like camels and goats were confirmed as means of transmission of plague to humans. ${ }^{14-17}$

\section{Past and present distribution of human plague in Africa}

Human plague remains of major public health importance in Africa. The continent has the highest incidence of plague.
African cases account for more than $90 \%$ of all human cases reported worldwide. ${ }^{18-20}$ The countries most affected are the Democratic Republic of the Congo (former Zaire), Madagascar, Mozambique, Uganda, and the United Republic of Tanzania. The Democratic Republic of the Congo and Madagascar are the countries with the highest endemicity in the world..$^{18,19}$

Active foci of human plague in Africa are known to exist in Algeria, ${ }^{21}$ Democratic Republic of the Congo, ${ }^{12}$ Libya,${ }^{22}$ Madagascar, ${ }^{19}$ Mozambique, ${ }^{23}$ Tanzania, ${ }^{24}$ Uganda,${ }^{23}$ and Zambia (Figure 1). ${ }^{25}$ In addition, Africa includes countries with a history of human plague and possibly zoonotic foci are currently present. Such zoonotic foci can initiate human disease re-emergence. In these countries, the epidemiological situation of recent epidemics of the disease is not available in the literature; however, previous epidemics were reported from Angola, ${ }^{26-30}$ Botswana, ${ }^{31-34}$ Burkina Faso, ${ }^{35,36}$ Egypt, ${ }^{37-39}$ Equatorial Guinea, ${ }^{7,40}$ Ghana, ${ }^{41}$ Kenya, ${ }^{28,32,42-48}$ Lesotho, ${ }^{49}$ Malawi, ${ }^{23,50-53}$ Mauritania, ${ }^{54}$ Morocco, ${ }^{55}$ Namibia, ${ }^{52,56,57}$ Nigeria, ${ }^{58}$ Republic of Guinea, ${ }^{1,36,59}$ Senegal ${ }^{60-62}$ Somalia, ${ }^{36}$ South Africa, ${ }^{63}$ South Sudan (in Juba) ${ }^{47}$ Tunisia, ${ }^{64}$ and Zimbabwe (Figure 1). ${ }^{50-52,63,65-67}$ The number of plague outbreaks in these countries has declined considerably during the last decades. However, this does not exclude that the infection persists in many areas where human plague has not been apparent for years. Recent outbreaks have shown that plague can re-emerge in areas that have long remained silent for example Algeria in 2003, after 48 years of silence. ${ }^{19}$ Some factors like civil wars, climate change, commercial exchanges, deforestation, migration, mining, poverty, and urbanization may be responsible for re-emergence of the disease. ${ }^{68,69}$ To better understand the current perspectives on the spread of plague in Africa, it seems reasonable to review the past and present situation of plague in countries with active human disease foci.

In Algeria, three large epidemics of the disease were reported during the first half of the 20th century, in 1921 in Oran and Algiers, in 1931 in Constantine, and in 1944 in the White City. In addition, many sporadic cases were reported mostly in ports. ${ }^{70-72}$ Until 2003, no natural focus of plague had ever been described in Algeria. In 2003, an outbreak of bubonic plague occurred in Oran where the last reported human case was in $1946 .{ }^{23,73-75}$ Epidemiologic and molecular findings strongly suggested the existence of a local animal reservoir during this period (1946-2003), but it could not be determined. ${ }^{18,72,76}$ In 2008, a second focus of plague was detected in the Laghouat area, southwest of Algiers. ${ }^{21}$ 


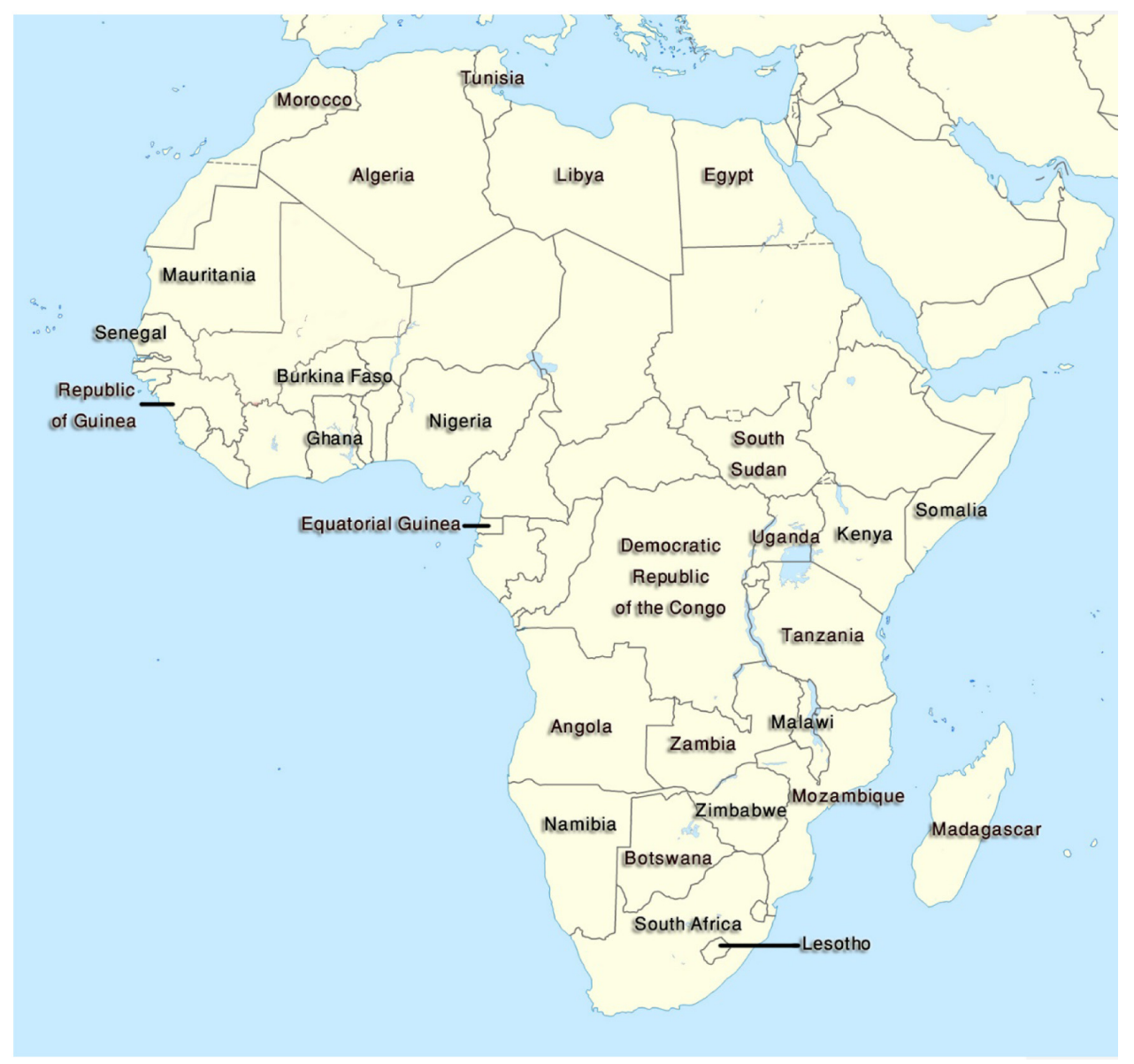

Figure I African countries in which human cases of plague were reported.

In the Democratic Republic of the Congo two endemic foci of plague have been reported in the first half of the 20th century. The first was detected in Ituri in 1928, the other in North-Kivu in 1938. Both foci are situated in the region of the great East-African Rift adjacent to the Ugandan focus, identified in 1877. Since then several flare-ups have been notified in different areas of the country mostly in its northern part. ${ }^{1,18,23,52,77-82}$ The WHO in 2000 reported that the country has notified cases of human plague virtually every year. ${ }^{59}$ Between 2004 and 2009, the country reported a cumulative total of 7,811 cases of human plague, including 402 deaths. This means clearly that the country had the highest endemicity in the world during this period. The high incidence of plague in the country has been attributed to the conflict during the 1990s, its consequent destruction of the health care system, and the displacement of people. ${ }^{19}$ Unfortunately, the lack of specific resources and appropriate means, the weakness of the surveillance system, and delays in diagnosis increase the risk that the existing foci will be extended ${ }^{83}$

Libya experienced several plague outbreaks during the period from 1913 to 1920 . The largest of these epidemics resulted in 1,449 deaths in Benghazi in 1917. Other epidemics of lower amplitude occurred in 1972, 1976, and 1977. ${ }^{84}$ The cases reported during such outbreaks were from foci scattered over a vast area of the country. This was evidence that an extensive epizootic of plague had taken place. Reports of human plague in 1976 in areas where sick camels and goats existed alerted to the role of these animals in the epidemiology of the disease in some areas. ${ }^{14,84}$ More cases of bubonic plague were diagnosed in 1984 in two locations $25 \mathrm{~km}$ from Tobruk where plague foci had been noted between 1976 and $1977 .{ }^{85} \mathrm{After}$ an apparent absence for 25 years, plague cases recurred in 2009 near Tobruk. A more recent plague epidemic was reported in 2011 in the city of Tobruk. ${ }^{22}$

Human plague was first introduced into Madagascar in the coastal city Toamasina in $1898,{ }^{86}$ most probably via infected rats on steam ships from India. ${ }^{87}$ Outbreaks in other coastal cities were then reported. In 1921, plague extended to the high plateau, above 700 meters, where it has persisted endemically. ${ }^{86}$ The disease then disappeared from the coast but became established in the central highlands and the capital city of Antananarivo, where it remains to this day. 
The disease is notified mainly in four provinces Antananarivo, Fianarantsoa, Mahajanga, and Toamasina. ${ }^{19,23,52,78,86,88}$ The Plague National Control Program was instituted in 1994 for surveillance and standardized notification. The mission of the central plague laboratory, based in the Institut Pasteur of Madagascar, is to collect and manage epidemiological and biological data, and a computerized database was set up for this purpose in $1995 .{ }^{83}$ Currently the disease is a significant human health problem, and hundreds of cases are reported each year. ${ }^{8,19}$ Madagascar reported a cumulative total of 3,454 cases, including 364 deaths, during 2004-2009. ${ }^{19}$ The country is reporting almost one-third of human cases worldwide. ${ }^{89}$ This could be attributed to the country collection of factors involved in disease re-emergence in other parts of the world in various environments. ${ }^{69,90,91}$ The risk factors that are associated with persistence and spread of plague in Madagascar will be discussed in detail in a separate section.

In Mozambique, a mild epidemic of plague broke out among the natives in the Govuro district in $1905 . .^{92}$ In 1977 , an outbreak was detected in Mutarara (Tete Province). ${ }^{93}$ In 1994, an outbreak was reported in Mutarara and Murrumbala (Zambezia province). ${ }^{94}$ During the period 1997-2003 a continuous outbreak was reported in Mutarara and Murrumbala. $^{23,51,52,78}$

In the United Republic of Tanzania, the disease is present in many parts because of the existence of suitable rodent reservoirs, efficient flea vectors, and favorable climatic conditions. ${ }^{95}$ Since the beginning of the 20 th century, sporadic outbreaks have occurred in some foci. ${ }^{95}$ However, many of these small outbreaks passed unrecorded as medical and health facilities in many areas were too inadequate to allow diagnosis and confirmation of the disease. ${ }^{96}$ Since 1983, outbreaks of human plague have occurred almost nonstop, which had not been the case for the previous 30-year period. ${ }^{18,23,24,32,50-52,66,67,78,85,97-102}$

In Uganda, the earliest documented cases of plague were recorded by missionaries in $1877 .{ }^{103}$ During the first half of the 20th century, the main plague foci in Uganda were localized in the Ituri forest, around Lake Albert, Burungu Island in Lake Victoria, Rubaga hill near Kampala and the Kyaggwe areas in the districts of Mukono, Masaka, Rakai, Pallisa, Tororo, and Busia. These districts eventually became quiescent except for two villages in the Toro District. ${ }^{45}$ The main active plague foci are in the West Nile region of Northwest Uganda bordering the Eastern Province of the Democratic Republic of the Congo where human plague is frequent. Outbreaks occurred in $1982,{ }^{63} 1986,{ }^{97} 1993,{ }^{104}$ $1998,{ }^{52} 2000,{ }^{78} 2001,{ }^{78}$ and $2002 .{ }^{23}$ In recent times, most of the plague cases in the West Nile region were reported from the southern Nebbi District. Since 1998, plague cases began to be reported from the northern Arua District. ${ }^{103}$

In Zambia, periodic epizootic cases of plague have occurred in the eastern and southern parts of the country. ${ }^{105-107}$ The first confirmed major outbreak of plague in Zambia was in the Southern Province, Namwala District in December 1996 to February 1997. ${ }^{51,106}$ Since then, many sporadic outbreaks occurred mainly in the eastern and southern parts of Zambia. ${ }^{25,78}$

\section{Risk factors in the persistence and spread of plague in Madagascar Ecological factors}

Madagascar, officially the Republic of Madagascar, is an island country in the Indian Ocean, off the coast of Southeast Africa (Figure 1). The nation comprises the island of Madagascar, as well as numerous smaller peripheral islands. As mentioned above, Madagascar is one of the most plagueaffected countries in the world where human plague foci have continued for decades. ${ }^{91}$ The long-term maintenance of plague in defined ecological niches may inform us about the environmental conditions that are required for plague to establish in permanent foci. ${ }^{68}$

In Madagascar, plague is mainly a rural disease that affects the central highlands and is associated with agricultural activities. ${ }^{19,91}$ Such activities and storage of crops within houses attract rats..$^{90,108}$ The high transmission season of the disease to humans has been associated with low abundance of rats and the high chance of accession of fleas to human dwellings. ${ }^{109-111}$ In the central highlands, most human cases are noted between September and March. This period is characterized by a warmer rainy climate than the low transmission season, which extends from April to August. ${ }^{91}$

Urban plague was mainly reported in Mahajanga (Majunga) harbor and the capital Antananarivo. ${ }^{112}$ The disease was first introduced into Mahajanga in 1902. A few cases were reported between 1907 and 1928, and then a period of silence in the coastal areas lasted more than 60 years. A sudden outbreak occurred in the harbor of Mahajanga in 1991, which was followed by subsequent epidemics from 1995 to 1998 during which 1,702 suspected cases were reported. ${ }^{113-117}$ In Mahajanga, outbreaks of human plague were reported from July to November which is the cool dry season. ${ }^{116}$ In Antananarivo city, outbreaks of human plague were first reported in $1921 .{ }^{86}$ After 58 years of quiescence, the disease re-emerged in 1979 and sporadic cases were noted. ${ }^{118}$ 
In Antananarivo, human cases are mostly reported during the warm rainy season from October to April. ${ }^{116}$

Deforestation and bushfires are also incriminated in promoting spread of rats and dissemination of plague. ${ }^{69,119,120}$ Deforestation has two consequences: the first consequence relates to the possibility of enhanced contact opportunities of humans with sylvatic plague in the forests of the High Plateau; the second consequence relates to the change in landscapes favoring the development of rodent populations as plague reservoirs. ${ }^{69,120,121}$

In plague foci, the disease system is the net result of complex interactions between its components, the densities, life cycle, dynamics, and geographical distributions, all of which are individually influenced by climate variables. ${ }^{68}$ Climate change influences the dynamics of flea and rodent hosts with responses varying considerably among species. ${ }^{68}$ Temperature, rainfall, and relative humidity have significant effects on survival, behavior, development, and reproduction of fleas. ${ }^{122-124}$ Effects of temperature on rodent populations are less clear, rodents are homoeothermic animals and hence do not respond immediately to changes in external temperatures. In temperate areas, low temperatures in winter can negatively affect rodent populations either directly or through food shortage. ${ }^{125}$ In addition, the survival of $Y$. pestis in rodents that interrupt their activities to hibernate through winter or estivate in summer could affect or prevent the transient temporal and spatial extinction of plague occurrence. ${ }^{126,127}$ Plague's epidemiology in Madagascar is affected by local climate factors which in turn are influenced by large-scale climate phenomena such as the El Niño Southern Oscillation and the Indian Ocean Dipole. The intensity of El Niño Southern Oscillation and Indian Ocean Dipole events and corresponding increases in temperature and rainfall, show strong associations with an increase in plague incidence in Madagascar. The seasonality of the disease confirms such strong link between disease transmission and optimal environmental conditions, via their effects on vector and host. ${ }^{89}$

\section{Biological factors}

The black rat, Rattus rattus, was the main rodent involved in the disease rural cycle in Madagascar. ${ }^{90}$ Rodent surveys initiated in the 1990s documented that construction of modern houses and sewage networks in urban areas favored the replacement of $R$. rattus by Rattus norvegicus (the sewer rat). Black rats are arboreal and thatched roofs provided them with a highly suitable habitat, while modern human housing has favored the more subterranean and even partly aquatic sewer rat, thus reducing the possibilities of contact between rats and humans. ${ }^{90}$ Rat populations from plagueendemic foci (central highland) are highly resistant to plague, whereas rat populations from low altitude zones where the disease is absent are susceptible. ${ }^{128,129}$ This natural resistance may explain the maintenance of plague in endemic foci. ${ }^{128}$ However, the immune response to infection may differ even for the same species of rat from the same endemic focus. ${ }^{130}$ Genetic structure analysis of $R$. rattus populations in a rural plague focus showed that ecology may support selection for resistance to plague. ${ }^{131}$ Sylvatic plague is much less frequent in the country. It occurs in Malagasy primary forests where invasive $R$. rattus and endemic small mammals coexist and can sustain transmission through endemic fleas. ${ }^{132}$ In such foci several species of small mammals such as shrews (subfamily Oryzorictinae) and tenrecs (subfamily Tenrecinae) were found infected. ${ }^{69}$ Human infections were reported among hunters and charcoal burners in these foci.$^{90}$ It is well documented that deforestation plays an important role in the dissemination of sylvatic plague to humans. ${ }^{119}$ Persistence of $Y$. pestis bacteria in soil was suspected in the country. ${ }^{86}$ Thus rodents may become infected by burrowing in contaminated soil. Although the exact mode of infection is unclear, previous studies have demonstrated the survival of the bacteria in soil for at least 24 days under natural conditions. ${ }^{133}$ In contradistinction, recent studies suggested that although the bacteria may remain viable and virulent in soil, the transmission route by experimental exposure of susceptible mice to contaminated soil seems unlikely under natural conditions. Indeed, the infectious period was short-lived and the transmission efficiency was low. ${ }^{134}$

Two species of fleas, $X$. cheopis and Synopsyllus fonquerniei, are known as the primary vectors of plague in Madagascar..$^{90}$ In the Central Highlands, S. fonquerniei is found only on rats caught outdoors and shows a clear seasonal cycle, thriving in the middle and at the end of the dry and cold season. This seasonal cycle suggested that $S$. fonquernie $i$ is incriminated in initiating human plague epidemics. In contrast, $X$. cheopis is mainly found on rats caught indoors, and remains at relatively high abundance throughout the rainy season. ${ }^{111} P$. irritans may play a role in domestic human-to-human transmission of $Y$. pestis during outbreaks. ${ }^{8}$ Other species of fleas such as Paractenopsyllus spp., Tsaractenus sp., and Synopsyllus estra$d e i$ are incriminated in the transmission of sylvatic plague. ${ }^{69}$

\section{Cultural and socio-demographic factors}

Every society has its own culture regarding the interplay between those who are and those who were. Famadihana is a traditional ceremony of the Malagasy people known as the 
turning of the bones. People bring forth the corpses of their ancestors from tombs and rewrap them in fresh cloth, then dance with them around the tomb to live music. Once the dancing stops and the bundled corpses are put on the ground, family members lovingly run their fingers across the skeletal outline protruding through the shrouds. Bones and dust are moved about in an effort to sustain a human shape. ${ }^{135}$ Onsets of pneumonic plague during such ceremonies have been documented, suggesting that handling of potentially plagueinfected corpses may be the cause. ${ }^{69,108,111}$ Thus, the Malagasy Ministry of Health recommended a minimum period of 7 years between death and exhumation of a plague victim, and before any transfer of a corpse from one village to another. ${ }^{69}$ Migration and transportation of goods containing infected rats or fleas is another factor favoring rapid transmission of plague in the country. ${ }^{136}$ Poverty associated with overcrowded dwellings favors disease transmission and outbreaks in urban settings. ${ }^{90}$ In remote rural areas, people often prefer consulting traditional healers instead of health centers, thus delaying the implementation of an effective chemotherapy. ${ }^{137}$

\section{Antimicrobial resistance}

Although, antimicrobial resistance in $Y$. pestis is rare, it constitutes a significant public health threat given that antimicrobials are critical both for plague treatment and prevention of human-to-human transmission. ${ }^{138}$ Such drug resistance has been documented for only a few strains. The best available information is for two strains isolated in Madagascar in 1995, in which resistance was conferred by plasmids not typically found in $Y$. pestis. Strain 16/95 was isolated in the Ampitana district from a 14-year-old male presenting with symptoms of bubonic plague. The strain was resistant to streptomycin only and the resistance was mediated by plasmid pIP1203. ${ }^{139}$ Strain 17/95 was isolated in the Ambalavao district from a 16-yearold male presenting with symptoms of bubonic plague. The strain was resistant to eight antimicrobial drugs, including some commonly used to treat plague, such as streptomycin, tetracyclines, and sulfonamides. ${ }^{3}$ Multidrug resistance in 17/95 was mediated by plasmid pIP1202. ${ }^{140}$ Both plasmids, pIP1203 and pIP1202, could be transferred by conjugation from the source $Y$. pestis strains to other Y.pestis strains and Escherichia coli. ${ }^{139,140}$ Plasmid pIP1203 could be transferred from $E$. coli to $Y$. pestis in the midgut of co-infected fleas. ${ }^{141}$

\section{Surveillance, prevention, and control of human plague}

Plague is still endemic in Africa and it is far from being eradicated. ${ }^{8,36,142}$ This is primarily because the disease is widespread in wildlife rodent reservoir hosts. Moreover, plague is especially aggressive in areas with weak health care systems and few resources like most African countries. ${ }^{142}$ Thus public health officials must have a plan to respond quickly to disease outbreaks. ${ }^{143}$ Effective prevention and control programs require up-to-date information on incidence and geographical distribution of the disease. The best means of obtaining such information is through a surveillance program that collects, analyzes, and interprets clinical, epidemiological, and epizootiological data on the disease. Accumulated surveillance data will provide information that could be used to predict areas where future human cases and rodent epizootics may occur; identify the most common zoonotic sources of human infection; identify the most important host species maintaining a given focus of plague; indicate the host species that should be targets for control measures; assess the effectiveness of disease prevention and control measures; identify factors that may result in increased plague exposure risks for humans; and detect trends in the epidemiology and epizootiology of plague in a given area. ${ }^{59,83,144}$

Many measures are recommended to lower the risk of getting plague in suspected disease foci. Public health education of citizens and the medical community is very important. Healthy people are advised to use personal protective equipment when handling sick or dead animal bodies. They should avoid even touching infected tissues, materials, or body fluids from a plague-infected person or animal. A minimum of three feet should be kept between them and anyone who may have pneumonic plague. Otherwise, they should use gloves plus face and eye protection. Also, they should avoid rodents and their droppings. They should avoid insect bites by using insect repellents, and get rid of insects especially fleas from their dwellings. In addition, it is recommended for healthy people in such areas to wash hands regularly and avoid touching their eyes, nose, and mouth. As post-exposure prophylaxis is indicated in persons with known exposure to plague, recommendations may include antibiotics for people who are at risk of illness. ${ }^{145}$ Plague vaccines have been developed for human use. ${ }^{146,147}$ However, none of these vaccines is commercially available, and their safety and efficacy have not been adequately tested. ${ }^{148}$

Control of human plague involves diagnosis of the infection, isolation of the patient and immediate contacts, focal attack on the area invaded by plague through disinfestation of premises and persons with insecticide. Sick people should begin appropriate chemotherapy as soon as plague is suspected. The drugs of choice are gentamicin or 
streptomycin, but chloramphenicol, fluoroquinolones (such as ciprofloxacin) and tetracyclines (such as doxycycline) are also effective. ${ }^{145,149,150}$ Control of plague transmission, from animal to animals or humans, can be most rapidly affected by control of the flea vector. The flea is the primary objective, the rat is secondary. In foci where flea populations are high and plague infections intense, killing rodents may result in the release of large numbers of avid fleas carrying plague organisms seeking new hosts. ${ }^{143,151}$

Noteworthy, the WHO has recommended a four-phased system of plague prevention and control that can be adapted to the requirements and resources of different countries. The first two phases of this system address emergency measures to be implemented whenever a human plague case occurs. Phase one concentrates mainly on case recognition and medical intervention. Phase two of the program should be initiated immediately following phase one. It includes an intensive environmental investigation of potential exposure sites for the human case(s) and initiation of emergency control measures to prevent additional cases. Phase three aims at establishment of a surveillance and control program. Finally, phase four is mainly a long-term management of plague foci in the country. ${ }^{152}$

\section{Conclusion and future perspectives}

Plague is endemic in many countries across Africa. The top two countries with the highest endemicity in the world are present in the continent. In addition, human plague is re-emerging in African countries where the disease was thought to have disappeared. A focus of plague may be dormant for many years, during which no human cases are reported. Subsequently, for reasons which may be natural or man-made changes, cases of human plague may occur suddenly. Factors like civil wars, climate change, commercial exchanges, deforestation, migration, mining, poverty, and urbanization may be responsible for re-emergence of the disease. Some preventive measures should be implemented in all the African countries, including surveillance of suspected natural foci, rodent and insect eradication campaigns, and public health education.

\section{Disclosure}

The author reports no conflicts of interest in this work.

\section{References}

1. Tikhomirov E. Epidemiology and distribution of plague. In: Dennis DT, Gage KL, Gratz NG, Poland JD, Thikhomirov E, editors. Plague Manual: Epidemiology, Distribution, Surveillance and Control. Geneva, Switzerland: World Health Organization; 1999:11-41.
2. Perry RD, Fetherston JD. Yersinia pestis: etiologic agent of plague Clin Microbiol Rev. 1997;10(1):35-66.

3. Galimand M, Carniel E, Courvalin P. Resistance of Yersinia pestis to antimicrobial agents. Antimicrob Agents Chemother. 2006;50(10): 3233-3236.

4. Devignat R. [Varieties of Pasteurella pestis; new hypothesis]. Bull World Health Organ. 1951;4(2):247-263.

5. Anisimov AP, Lindler LE, Pier GB. Intraspecific diversity of Yersinia pestis. Clin Microbiol Rev. 2004;17(2):434-464.

6. Li Y, Cui Y, Hauck Y, et al. Genotyping and phylogenetic analysis of Yersinia pestis by MLVA: insights into the worldwide expansion of Central Asia plague foci. PLoS ONE. 2009;4(6):e6000.

7. Gratz NG. Rodent reservoirs and flea vectors of natural foci of plague. In: Dennis DT, Gage KL, Gratz NG, Poland JD, Thikhomirov E, editors. Plague Manual: Epidemiology, Distribution, Surveillance and Control. Geneva, Switzerland: World Health Organization; 1999:63-96.

8. Ratovonjato J, Rajerison M, Rahelinirina S, Boyer S. Yersinia pestis in Pulex irritans fleas during plague outbreak, Madagascar. Emerg Infect Dis. 2014;20(8):1414-1415.

9. von Reyn CF, Weber NS, Tempest B, et al. Epidemiologic and clinical features of an outbreak of bubonic plague in New Mexico. J Infect Dis. 1977;136(4):489-494.

10. Ayyadurai S, Sebbane F, Raoult D, Drancourt M. Body lice, Yersinia pestis Orientalis, and Black Death. Emerg Infect Dis. 2010;16(5):892-893.

11. Tran TN, Forestier CL, Drancourt M, Raoult D, Aboudharam G. Brief communication: co-detection of Bartonella quintana and Yersinia pestis in an 11th-15th burial site in Bondy, France. Am J Phys Anthropol. 2011;145(3):489-494.

12. Piarroux R, Abedi AA, Shako JC, et al. Plague epidemics and lice, Democratic Republic of the Congo. Emerg Infect Dis. 2013;19(3): 505-506.

13. Dennis D, Meier F. Plague. In: Horsburgh CR, Nelson AM, editors. Pathology of Emerging Infections. Washington, DC: ASM Press; 1997:21-47.

14. Christie AB, Chen TH, Elberg SS. Plague in camels and goats: their role in human epidemics. J Infect Dis. 1980;141(6):724-726.

15. Arbaji A, Kharabsheh S, Al-Azab S, et al. A 12-case outbreak of pharyngeal plague following the consumption of camel meat, in north-eastern Jordan. Ann Trop Med Parasitol. 2005;99(8):789-793.

16. Bin Saeed AA, Al-Hamdan NA, Fontaine RE. Plague from eating raw camel liver. Emerg Infect Dis. 2005;11(9):1456-1457.

17. Leslie T, Whitehouse CA, Yingst S, et al. Outbreak of gastroenteritis caused by Yersinia pestis in Afghanistan. Epidemiol Infect. 2011;139(5): 728-735.

18. WHO. International meeting on preventing and controlling plague: the old calamity still has a future. Wkly Epidemiol Rec. 2006;81(28):278-284.

19. WHO. Human plague: review of regional morbidity and mortality 2004-2009. Wkly Epidemiol Rec. 2010;85(6):40-45.

20. Bertherat E, Thullier P, Shako JC, et al. Lessons learned about pneumonic plague diagnosis from 2 outbreaks, Democratic Republic of the Congo. Emerg Infect Dis. 2011;17(5):778-784.

21. Bitam I, Ayyadurai S, Kernif T, et al. New rural focus of plague, Algeria. Emerg Infect Dis. 2010;16(10):1639-1640.

22. Cabanel N, Leclercq A, Chenal-Francisque V, et al. Plague outbreak in Libya, 2009, unrelated to plague in Algeria. Emerg Infect Dis. 2013;19(2):230-236.

23. WHO. Human plague in 2002 and 2003. Wkly Epidemiol Rec. 2004;79(33):301-306

24. Ziwa MH, Matee MI, Hang'ombe BM, Lyamuya EF, Kilonzo BS. Plague in Tanzania: an overview. Tanzan J Health Res. 2013;15(4).

25. Hang'ombe BM, Nakamura I, Samui KL, et al. Evidence of Yersinia pestis DNA from fleas in an endemic plague area of Zambia. BMC Res Notes. 2012;5:72.

26. Mora AD. Apontamentos sobre a epidemia da peste bubónica em Loanda - Fevereiro a Junho de 1921 [Notes on bubonic plague epidemic in Loanhead - February to June 1921]. Rev Méd Angola. 1921;1:11-153. Portuguese. 
27. Mora AD. A segunda epidemia da peste em Loanda. Setembro, Outubro e Novembro de 1922. Rev Méd Angola. [The second epidemic of plague in Loanhead. September, October and November 1922]. 1922;3: 102-117. Portuguese.

28. WHO. Human plague in 1980. Wkly Epidemiol Rec. 1981;35:273-275.

29. WHO. Human plague in 1981. Wkly Epidemiol Rec. 1982;38:289-291.

30. dos Santos Gracio AJ, Gracio MAA. Plague in Angola. Acta Parasitol Port. 2011;18(1/2):1-10.

31. WHO. Human plague in 1989. Wkly Epidemiol Rec. 1990;42:321-323.

32. WHO. Human plague in 1990. Wkly Epidemiol Rec. 1991;44:321-324.

33. Kumaresan JA, Grova JB, Mmatli PK, Maganu ED. An experience in the control of plague in Botswana. Trop Doct. 1991;21(4): $142-146$.

34. Kumaresan JA, Grova JB, Mmatli PK, Magany ED. Plague in Botswana. Cent Afr J Med. 1991;37(8):271-272.

35. Whitty CJM. Plague. In: Parry E, Godfrey R, Mabey D, Gill G, editors. Principles of Medicine in Africa. 3rd ed. Cambridge, UK: Cambridge University Press; 2004:615-619.

36. Neerinckx S, Bertherat E, Leirs H. Human plague occurrences in Africa: an overview from 1877 to 2008. Trans R Soc Trop Med Hyg. 2010;104(2):97-103.

37. Hussein AG. Changes in the epidemiology of plague in Egypt, 1899-1951. Bull World Health Organ. 1955;13(1):27-48.

38. Mollaret HH. Dissimulation et négation de la peste [Concealing and denying the plague]. Hist Sci Med. 1995;29(4):343-345. French.

39. Panagiotakopulu E. Pharaonic Egypt and the origins of plague. J Biogeogr. 2004;31(2):269-275.

40. Akiev AK. Epidemiology and incidence of plague in the world, 1958-79. Bull World Health Organ. 1982;60(2):165-169.

41. David S. Epidemic Disease in Ghana, 1901-1960. Toronto, Canada: Oxford University Press; 1965.

42. Roberts JI. The endemicity of plague in East Africa. East Afr Med J. $1935 ; 12: 200-219$.

43. Roberts JI. Plague conditions in an urban area of Kenya (Nairobi Township). J Hyg (Lond). 1936;36(4):467-484.

44. Heisch RB. Rodents as reservoirs of arthropod-borne diseases in Kenya. East Afr Med J. 1961;38(5):256-261.

45. Davis DH, Heisch RB, McNeill D, Meyer KF. Serological survey of plague in rodents and other small mammals in Kenya. Trans $R$ Soc Trop Med Hyg. 1968;62(6):838-861.

46. Siongok TKS, Njagi AM, Masaba S. Another focus of sylvatic plague in Kenya. East Afr Med J. 1977;54(12):694-698.

47. WHO. Human plague in 1979. Wkly Epidemiol Rec. 1980;32:241-244.

48. Schwan TG. Seasonal abundance of fleas on grassland rodents in Lake Nakuru National Park, Kenya and potential for plague transmission. Bull Entomol Res. 1986;76(4):633-648.

49. Isaacson M, Qhobela QM, Davis DH, Growngold TP. Serological studies on human plague in Southern Africa. Part II. A bubonic/pneumonic plague epidemic in Lesotho. S Afr Med J. 1976;50(24):929-932.

50. WHO. Human plague in 1994. Wkly Epidemiol Rec. 1996;22:165-168.

51. WHO. Human plague in 1997. Wkly Epidemiol Rec. 1999;74:340-344.

52. WHO. Human plague in 1998 and 1999. Wkly Epidemiol Rec. 2000; 75(42):338-343

53. Riedel S. Plague: from natural disease to bioterrorism. Proc (Bayl Univ Med Cent). 2005;18(2):116-124.

54. Klein JM, Alonso JM, Baranton G, Poulet AR, Mollaret HH. Plague in Mauritania. Med Mal Infect. 1975;5(4):198-207.

55. Anonymous. Morocco: Reappearance of plague in Doukala Province. Public Health Reports (1896-1970). 1911;26(45):1774-1775. Available from: http://www.ncbi.nlm.nih.gov/pmc/articles/PMC1999120/pdf/ pubhealthreporig03636-0001.pdf. Accessed April 15, 2015.

56. Williams JE, Arntzen L, Tyndal GL, Isaacson M. Application of enzyme immunoassays for the confirmation of clinically suspect plague in Namibia, 1982. Bull World Health Organ. 1986;64(5):745-752.

57. Shangula K. Successful plague control in Namibia. S Afr Med J. 1998;88(11):1428-1430.
58. Anonymous. Health prevalence of disease: Foreign and insular. Public Health Reports (1896-1970). 1925;40(8):389-399. Available from: http://www.ncbi.nlm.nih.gov/pmc/articles/PMC1975989/?page=59. Accessed April 15, 2015.

59. WHO. WHO Report on Global Surveillance of Epidemic-Prone Infectious Diseases. Geneva, Switzerland: World Health Organization. Available from: http://www.who.int/csr/resources/publications/surveillance/plague.pdf. Accessed March 27, 2015.

60. Damez A. Le probleme de la peste dans les colonies françaises. Lyon, France: Bosc Frères, M. and L. Riou; 1933.

61. Kartman L. A note on the problem of plague in Dakar, Senegal, French West Africa. J Parasitol. 1946;32:30-35.

62. Kaul PM. Prevalence of plague in the world in recent years. Epidemiol. Vital Stat Rep. 1949;2:143-165

63. WHO. Human plague in 1982. Wkly Epidemiol Rec. 1983;58:265-266.

64. Anonymous. Tunis: Tunis Plague. Public Health Reports (1896-1970). 1910;25(34):1196. Available from: http://www.ncbi.nlm.nih.gov/pmc/ articles/PMC1999320/?page=24. Accessed April 15, 2015.

65. Taylor P, Gordon DH, Isaacson M. The status of plague in Zimbabwe. Ann Trop Med Parasitol. 1981;75(2):165-173.

66. WHO. Human Plague in 1983. Wkly Epidemiol Rec. 1984;38:289-290.

67. WHO. Human Plague in 1985. Wkly Epidemiol Rec. 1986;36:273-274.

68. Ben-Ari T, Neerinckx S, Gage KL, et al. Plague and climate: scales matter. PLoS Pathog. 2011;7(9):e1002160.

69. Andrianaivoarimanana V, Kreppel K, Elissa N, et al. Understanding the persistence of plague foci in Madagascar. PLoS Negl Trop Dis. 2013;7(11):e2382.

70. Raynaud L. La peste en Algérie. Arch Inst Pasteur Alger. 1924;II: 303-361.

71. Mafart B, Brisou P, Bertherat E. Epidémiologie et prise en charge des épidémies de peste en Méditerranée au cours de la Seconde Guerre Mondiale. [Plague outbreaks in the Mediterranean area during the 2nd World War, epidemiology and treatments]. Bull Soc Pathol Exot. 2004;97(4):306-310. French.

72. Bertherat E, Bekhoucha S, Chougrani S, et al. Plague reappearance in Algeria after 50 years, 2003. Emerg Infect Dis. 2007;13(10): 1459-1462.

73. Roux AH, Mercier C. Sur cinq cas de peste pulmonaire primitive dont trois suivis de guérison, observés à l'hôpital civil d'Oran. Bull Soc Pathol Exot. 1946;36:173-178. French.

74. WHO. Plague, Algeria. Wkly. Epidemiol Rec. 2003;78(29):253-260.

75. Lounici M, Lazri M, Rahal K. La peste en Algerie: a propos de cinq souches de Yersinia pestis isolees lors de l'epidemie de juin 2003 [Plague in Algeria: about five strains of Yersinia pestis isolated during the outbreak of June 2003]. Pathol Biol (Paris). 2005;53(1):15-18. French.

76. Bitam I, Baziz B, Rolain JM, Belkaid M, Raoult D. Zoonotic focus of plague, Algeria. Emerg Infect Dis. 2006;12(12):1975-1977.

77. Janssens PG, Pattyn SR. Pest in Zaïre [Plague in Zaire]. Verh K Acad Geneeskd Belg. 1994;56(4):281-360. Dutch.

78. WHO. Human plague in 2000 and 2001. Wkly Epidemiol Rec. 2003;78(16):130-135.

79. WHO. Plague, Democratic Republic of the Congo. Wkly Epidemiol Rec. 2005;80(8):65.

80. WHO. Plague, Democratic Republic of the Congo - update. Wkly Epidemiol Rec. 2005;80(8):65.

81. WHO. Plague, Democratic Republic of the Congo. Wkly Epidemiol Rec. 2006;81(25):241-242.

82. WHO. Plague, Democratic Republic of the Congo. Wkly Epidemiol Rec. 2006;81(42):397-398.

83. WHO. Interregional Meeting on Prevention and Control of Plague. Geneva, Switzerland: World Health Organization; 2008.

84. Misonne X. A natural focus of plague in Libya. Ann Soc Belg Med Trop. 1977;57(3):163-168.

85. WHO. Human plague in 1984. Wkly Epidemiol Rec. 1985;39: 297-298. 
86. Brygoo ER. Epidémiologie de la peste à Madagascar [Epidemiology of plague in Madagascar]. Arch Inst Pasteur Madagascar. 1966;35: 9-147. French.

87. Morelli G, Song Y, Mazzoni CJ, et al. Yersinia pestis genome sequencing identifies patterns of global phylogenetic diversity. Nat Genet. 2010;42(12):1140-1143.

88. Chanteau S, Ratsifasoamanana L, Rasoamanana B, et al. Plague, a reemerging disease in Madagascar. Emerg Infect Dis. 1998;4(1): 101-104.

89. Kreppel KS, Caminade C, Telfer S, et al. A non-stationary relationship between global climate phenomena and human plague incidence in Madagascar. PLoS Negl Trop Dis. 2014;8(10):e3155.

90. Duplantier JM, Duchemin JB, Chanteau S, Carniel E. From the recent lessons of the Malagasy foci towards a global understanding of the factors involved in plague reemergence. Vet Res. 2005;36(3): 437-453.

91. Rahelinirina S, Duplantier JM, Ratovonjato J, Ramilijaona O, Ratsimba M, Rahalison L. Study on the movement of Rattus rattus and evaluation of the plague dispersion in Madagascar. Vector Borne Zoonotic Dis. 2010;10(1):77-84.

92. Anonymous. Plague in Mozambique. Public Health Reports (1896-1970). 1905;20(19):881. Available from: http://www.ncbi.nlm. nih.gov/pmc/articles/PMC2081967/?page=35. Accessed April 15, 2015.

93. WHO. Human plague in 1977. Wkly Epidemiol Rec. 1978;37:273-275.

94. Barreto A, Aragon M, Epstein PR. Bubonic plague outbreak in Mozambique, 1994. Lancet. 1995;345(8955):983-984.

95. Msangi AS. Observations on the Endemicity of Plague in Tanzania. London, UK, University of London; 1968.

96. Kilonzo BS, Mhina JI. The first outbreak of human plague in Lushoto district, north-east Tanzania. Trans R Soc Trop Med Hyg. 1982;76(2): 172-177.

97. WHO. Human plague in 1986. Wkly Epidemiol Rec. 1987;40:299-300.

98. WHO. Human plague in 1987. Wkly Epidemiol Rec. 1988;47:360-362.

99. Kilonzo BS, Makundi RH, Mbise TJ. A decade of plague epidemiology and control in the western Usambara mountains, north-east Tanzania. Acta Trop. 1992;50(4):323-329.

100. Kilonzo BS, Mbise TJ, Mwalimu DC, Kindamba L. Observations on the endemicity of plague in Karatu and Ngorongoro, northern Tanzania Tanzan Health Res Bull. 2006;8(1):1-6.

101. Laudisoit A, Leirs H, Makundi RH, et al. Plague and the human flea, Tanzania. Emerg Infect Dis. 2007;13(5):687-693.

102. Ziwa MH, Matee MI, Kilonzo BS, Hang'ombe BM. Evidence of Yersinia pestis DNA in rodents in plague outbreak foci in Mbulu and Karatu Districts, northern Tanzania. Tanzan J Health Res. 2013;15(3).

103. Orochi-Orach S. Plague Outbreaks the Gender and Age Perspective in Okoro County, Nebbi District, Uganda. Nebbe, Uganda: Agency for Accelerated Regional Development; 2002.

104. WHO. Human plague in 1993. Wkly Epidemiol Rec. 1995;70(7): $45-48$.

105. McClean KL. An outbreak of plague in northwestern province, Zambia. Clin Infect Dis. 1995;21(3):650-652.

106. Mwase ET, Mwansa JC, Musonda MM. Plague outbreaks in Zambia: an overview. Zambia J Med Health Sci. 1999;3:50-54.

107. Ngulube TJ, Mwanza K, Njobvu CA, Muula AS. Knowledge, attitudes and public health response towards plague in Petauke, Zambia. Trop Doct. 2006;36(4):223-225.

108. Chanteau S. Atlas de la peste à Madagascar. Paris, France: IRD Editions; 2006

109. Duplantier JM, Rakotondravony D. The rodent problem in Madagascar: agricultural pest and threat to human health. In: Singleton G, Linds L, Leirs H, Zhang Z, editors. Ecologically-Based Rodent Management. Canberra, Australia: ACIA; 1999:441-459.

110. Keeling MJ, Gilligan CA. Metapopulation dynamics of bubonic plague. Nature. 2000;407(6806):903-906.
111. Migliani R, Chanteau S, Rahalison L, et al. Epidemiological trends for human plague in Madagascar during the second half of the 20th century: a survey of 20,900 notified cases. Trop Med Int Health. 2006;11(8):1228-1237.

112. Chanteau S, Ratsitorahina M, Rahalison L, et al. Current epidemiology of human plague in Madagascar. Microbes Infect. 2000;2(1): $25-31$.

113. Rasolomaharo M, Rasoamanana B, Andrianirina Z, Buchy P, Rakotoarimanana N, Chanteau S. Plague in Majunga, Madagascar. Lancet. 1995;346(8984):1234.

114. Boisier P, Rasolomaharo M, Ranaivoson G, et al. Urban epidemic of bubonic plague in Majunga, Madagascar: epidemiological aspects. Trop Med Int Health. 1997;2(5):422-427.

115. Laventure S, Rasoamanana B, Boisier P, et al. Epidémies de peste urbaine à Majunga, côte ouest de Madagascar. Bull Soc Pathol Exot. 1998;91:85-86.

116. Boisier P, Rahalison L, Rasolomaharo M, et al. Epidemiologic features of four successive annual outbreaks of bubonic plague in Mahajanga, Madagascar. Emerg Infect Dis. 2002;8(3):311-316.

117. Vogler AJ, Chan F, Nottingham R, et al. A decade of plague in Mahajanga, Madagascar: insights into the global maritime spread of pandemic plague. MBio. 2013;4(1):e00623-12.

118. Coulanges P. Situation de la peste à Tananarive, de son apparition en 1921 à sa résurgence en 1979 [The plague in Tananarive (from its start in 1921 to its reappearance in 1979)]. Arch Inst Pasteur Madagascar. 1979;56(1):9-35. French.

119. Duplantier JM, Duchemin JB, Ratsitorahina M, Rahalison L, Chanteau S. Résurgence de la peste dans le district d'Ikongo à Madagascar en 1998. 2: Réservoirs et vecteurs impliqués [Resurgence of the plague in the Ikongo district of Madagascar in 1998. 2. Reservoirs and vectors implicated]. Bull Soc Pathol Exot. 2001;94(2):119-122. French.

120. Barrett MA, Brown JL, Junge RE, Yoder AD. Climate change, predictive modeling and lemur health: Assessing impacts of changing climate on health and conservation in Madagascar. Biol Conserv. 2013;157: 409-422.

121. Goodman SM. Rattus on Madagascar and the dilemma of protecting the endemic rodent fauna. Conserv Biol. 1995;9(2):450-453.

122. Krasnov BR, Khokhlova IS, Fielden LJ, Burdelova NV. Effect of air temperature and humidity on the survival of pre-imaginal stages of two flea species (Siphonaptera: Pulicidae). J Med Entomol. 2001;38(5): 629-637.

123. Krasnov BR, Khokhlova IS, Fielden LJ, Burdelova NV. Development rates of two Xenopsylla flea species in relation to air temperature and humidity. Med Vet Entomol. 2001;15(3):249-258.

124. Gage KL, Burkot TR, Eisen RJ, Hayes EB. Climate and vectorborne diseases. Am J Prev Med. 2008;35(5):436-450.

125. Korslund L, Steen H. Small rodent winter survival: snow conditions limit access to food resources. J Anim Ecol. 2006;75(1):156-166.

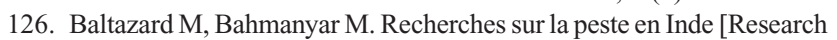
on plague in India]. Bull World Health Organ. 1960;23:169-215. French.

127. Bazanova LP, Nikitin AY, Popkov AF, Maevskii MP. Seasonal dynamics of epizootic process of the plague agent Yersinia pestis transmission to the long-tailed suslik Citellus undulatus by the flea Citellophilus tesquorum in Tuva. Entomological Review. 2007;87(6):685-691.

128. Rahalison L, Ranjalahy M, Duplantier J-M, et al. Susceptibility to plague of the rodents in Antananarivo, Madagascar. In: Skurnik M, Bengoechea JA, Granfors K, editors. Advances in Experimental Medicine and Biology. The Genus Yersini. Vol 529. New York, NY: Kluwer AcademicPlenum Publishers; 2003:439-442.

129. Tollenaere C, Rahalison L, Ranjalahy M, et al. Susceptibility to Yersinia pestis experimental infection in wild Rattus rattus, reservoir of plague in Madagascar. Ecohealth. 2010;7(2):242-247.

130. Andrianaivoarimanana $\mathrm{V}$, Telfer $\mathrm{S}$, Rajerison $\mathrm{M}$, et al. Immune responses to plague infection in wild Rattus rattus, in Madagascar: a role in foci persistence? PLoS One. 2012;7(6):e38630. 
131. Gilabert A, Loiseau A, Duplantier JM, et al. Genetic structure of black rat populations in a rural plague focus in Madagascar. Can J Zool. 2007;85(9):965-972.

132. Duchemin JB, Duplantier JM, Goodman S, Ratovonjato J, Rahalison L, Chanteau S. La peste à Madagascar: faune endémique et foyers sylvatiques. Proceedings of the Conference: La peste: entre épidémies et sociétés; 2007; July 23-26; 2001; Marseille, France.

133. Eisen RJ, Petersen JM, Higgins CL, et al. Persistence of Yersinia pestis in soil under natural conditions. Emerg Infect Dis. 2008;14(6): 941-943.

134. Boegler KA, Graham CB, Montenieri JA, et al. Evaluation of the infectiousness to mice of soil contaminated with Yersinia pestis-infected blood. Vector Borne Zoonotic Dis. 2012;12(11):948-952.

135. Bloch M. Placing the Dead: Tombs, Ancestral Villages, and Kinship Organization in Madagascar. London, UK: Seminar press; 1971.

136. Vogler AJ, Chan F, Wagner DM, et al. Phylogeography and molecular epidemiology of Yersinia pestis in Madagascar. PLoS Negl Trop Dis. 2011;5(9):e1319.

137. Ratsitorahina M, Chanteau S, Rahalison L, Ratsifasoamanana L, Boisier P. Epidemiological and diagnostic aspects of the outbreak of pneumonic plague in Madagascar. Lancet. 2000;355(9198): 111-113.

138. Welch TJ, Fricke WF, McDermott PF, et al. Multiple antimicrobial resistance in plague: an emerging public health risk. PLoS One. 2007;2(3):e309.

139. Guiyoule A, Gerbaud G, Buchrieser C, et al. Transferable plasmidmediated resistance to streptomycin in a clinical isolate of Yersinia pestis. Emerg Infect Dis. 2001;7(1):43-48.

140. Galimand M, Guiyoule A, Gerbaud G, et al. Multidrug resistance in Yersinia pestis mediated by a transferable plasmid. $N$ Engl J Med. 1997;337(10):677-680.

141. Hinnebusch BJ, Rosso ML, Schwan TG, Carniel E. High-frequency conjugative transfer of antibiotic resistance genes to Yersinia pestis in the flea midgut. Mol Microbiol. 2002;46(2):349-354.
142. Stenseth NC, Atshabar BB, Begon M, et al. Plague: past, present, and future. PLoS Med. 2008;5(1):e3.

143. Gratz NG. Control of plague transmission. In: Dennis DT, Gage KL, Gratz NG, Poland JD, Thikhomirov E, editors. Plague Manual: Epidemiology, Distribution, Surveillance and Control. Geneva, Switzerland: World Health Organization; 1999:97-134.

144. Gage KL. Plague surveillance. In: Dennis DT, Gage KL, Gratz NG, Poland JD, Thikhomirov E, editors. Plague Manual: Epidemiology, Distribution, Surveillance and Control. Geneva, Switzerland: World Health Organization; 1999:135-165.

145. Inglesby TV, Dennis DT, Henderson DA, et al. Plague as a biological weapon: medical and public health management. Working Group on Civilian Biodefense. JAMA. 2000;283(17):2281-2290.

146. Meyer KF, Cavanaugh DC, Bartelloni PJ, Marshall JD Jr. Plague immunization. I. Past and present trends. J Infect Dis. 1974;129:Suppl: S13-S18.

147. Cavanaugh DC, Elisberg BL, Llewellyn $\mathrm{CH}$, et al. Plague immunization. V. Indirect evidence for the efficacy of plague vaccine. J Infect Dis. 1974;129:Suppl:S37-S40.

148. Anonymous. Prevention of Plague: Recommendations of the Advisory Committee on Immunization Practices (ACIP). MMWR Recomm Rep. 1996;45(RR-14):1-15.

149. Poland JD, Dennis DT. Treatment of plague. In: Dennis DT, Gage KL, Gratz NG, Poland JD, Thikhomirov E, editors. Plague Manual: Epidemiology, Distribution, Surveillance and Control. Geneva, Switzerland: World Health Organization; 1999:55-62.

150. Koirala J. Plague: Disease, management, and recognition of act of terrorism. Infect Dis Clin North Am. 2006;20(2):273-287.

151. Gordon JE, Knies PT. Flea versus rat control in human plague. Am J Med Sci. 1947;213(3):362-376.

152. WHO. Plague surveillance and control. WHO Chron. 1980;34: $139-143$
Research and Reports in Tropical Medicine

\section{Publish your work in this journal}

Research and Reports in Tropical Medicine is an international, peerreviewed, open access journal publishing original research, case reports, editorials, reviews and commentaries on all areas of tropical medicine, including: Diseases and medicine in tropical regions; Entomology; Epidemiology; Health economics issues; Infectious disease; Laboratory

\section{Dovepress}

science and new technology in tropical medicine; Parasitology; Public health medicine/health care policy in tropical regions; and Microbiology. The manuscript management system is completely online and includes a very quick and fair peer-review system. Visit http://www.dovepress com/testimonials.php to read real quotes from published authors. 